\title{
PENGARUH HASIL PROGRAM PARENTING DAN POLA ASUH ORANG TUA TERHADAP PENINGKATAN MOTIVASI BELAJAR ANAK USIA DINI
}

(Survey terhadap Orang Tua pada TK ABA 3 Kota Padangsidimpuan)

\author{
Friska Indria Nora Harahap \\ Pendidikan Guru Raudhatul Athfal, Universitas Muhammadiyah Tapanuli Selatan \\ J1. Sutan Moh. Arief No.32, Batang Ayumi Julu, Kota Padang Sidempuan, \\ Sumatera Utara 22733 \\ Email : hrp.frischa@gmail.com
}

\begin{abstract}
This research is motivated by pebedaan motivation to learn every child, this is because difference of parenting pattern applied by parent to child. Patterns of parenting that is the pattern of foster democratic, authoritarian and permissive. Lack of parental knowledge about parenting is one of the factors that hinder children's learning motivation. But the knowledge is not only obtained by parents when the parenting program, some parents are able to obtain information about the care of other sources and able to provide good parenting. On the other hand, some other parents are not actively seeking information outside the activities that have been set. The purpose of this study is to provide information about: (1) the effect of parenting program on parenting parenting, (2) the influence of parenting pattern applied by parents (3) the influence of parenting program result and parenting pattern applied by parents to the improvement of early childhood learning motivation.

The study of the theory used in this research consisted of the concept of parenting, the concept of parenting program, the concept of early childhood education, the concept of parenting in the family, and the concept of early childhood motivation.

This research used survey method with cross-sectional study.Data approach collected using questionnaire technique. The population of this study were parenting participants in kindergarten ABA 3 Padangsidimpuandengan sample size 50 people.

Based on the results of the study, the following conclusions are concluded: (1) parents who participate in parenting program in ABA 3 kindergarten Padangsidimpuansebanyak can apply the materials delivered at the time the activities are carried out into the care of children every day. (2) parenting parenting partially influences to the improvement of early childhood learning motivation, (3) parenting program result and parenting pattern which together influence to motivation of early child learning.
\end{abstract}

Keywords: Parenting Program, Parents Parenting Patterns, Learning Motivation Early childhood. 


\section{A. Pendahuluan}

Pendidikan adalah usaha sadar dan terencana untuk mewujudkan suasana belajar dan proses pembelajaran agar peserta didik secara aktif mengembangkan potensi dirinya untuk memiliki kekuatan spiritual keagamaan, pengendalian diri, kepribadian, kecerdasan, akhlak mulia, serta keterampilan yang diperlukan dirinya, masyarakat, bangsa dan Negara. Menurut system pendidikan Nasional bahwa pendidikan dapat dilaksanakan melalui tiga jalur yaitu pendidikan formal, informal, nonformal. Ketiga jalur pendidikan tersebut sangatlah jelas berbeda antara pendidikan non formal dengan pendidikan formal dan informal. Pendidikan nonformal ini meliputi pendidikan anak usia dini, pendidikan kecakapan hidup, pendidikan kepemudaan, pendidikan kesetaran, pendidikan pemberdayaan perempuan, pendidikan keterampilan dan pelatihan kerja serta pendidikan lain yang ditunjukan untuk mengembangkan kemampuan peserta didik.

Pendidikan anak usia dini dianggap menjadi upaya untuk menjawab sebagaian dari permasalahan pendidikan dan penjaminan mutu sumber daya manusia di negeri ini. Salah satunya dengan upaya pemerintah dengan mengeluarkan aturan satu desa satu Paud yang terintegrasi dengan Posyandu yang menjadikan paud semakin menjamur di masyarakat. Hal demikian terjadi dikarenakan manfaat kedepan yang diperoleh oleh anak setelah mengeyam pendidikan sejak dini seperti, kemampuan bersosialisasai anak yang meningkat, rasa percaya diri, dan dapat merangsang motorik kasar dan halus anak, serta dapat melatih kreativitas anak.

Semua manfaat pendidikan sejak dini tersebut tidak sepenuhnya diperoleh oleh anak, dikarenakan banyak faktor salah satu diantaranya adalah faktor motivasi dari dalam diri anak. Banyak anak yang malas sekolah bahkan takut untuk pergi sekolah, dan pada kondisi seperti inilah dituntut orang tua yang mampu untuk menumbuhkan dan mendorong motivasi anak untuk belajar khususnya anak usia dini.

Orang tua mempunyai peranan yang sangat penting dalam hal pengasuhan. Namun kenyataannya banyak orang tua yang merasa kebingungan dalam hal pengasuhan anak. Akhirakhir ini sudah banyak cara yang dapat ditempuh mengenai bagaimana cara mendidik anak dengan baik sudah mulai digulirkan. Banyak orang tua yang tergugah dan berusaha mencari informasi sebanyak mungkin untuk mendapatkan pengetahuan mengenai pola asuh anak yang baik. Semua itu disebabkan karena banyak orang tua yang merasa tidak puas dengan didikan 
orang tuanya dulu sehingga ingin memberikan yang lebih baik bagi anak-anaknya. Namun adapula yang menyanggah dan mengatakan bahwa program parenting ini tidak perlu dan beralasan bahwa orang tuanya dulu tidak pernah ikut program parenting tetapi anak-anaknya berhasil dan sukses. Program parenting dirasa sebagai salah satu solusi sebagai upaya bimbingan agar orang tua dapat menerapkan pola asuh yang baik.

Berdasarkan kondisi objektif dilapagan, permasalahan motivasi belajar anak berbedabeda. Dilihat dari kehadiran anak didalam kelas peserta didik yang aktif berkisar $70 \%$. Namun motivasi belajar pada setiap harinya berbeda, hal ini dipengaruhi oleh pola asuh orang tua. Diantaranya orang tua yang acuh tak acuh, orang tua yang sibuk dengan urusan pribadinya, adapula orang tua yang peduli terhadap anaknya dalam memberikan motivasi belajar. Perbedaan pola asuh orang tua otoriter, demokratis, dan permisif sangat berpengaruh terhadap tingkat motivasi belajar anak. Oleh karena itu tidak heran jika setiap keluarga berbeda dengan keluarga lainnya. Pengaruh keluarga sangat besar dalam pembentukan landasan kepribadiaan anak khususnya motivasi anak dalam belajar.

Berdasarkan uraian latar belakang diatas, maka penulis tertarik untuk mencoba mengembangkan permasalahan dengan topik penelitian sebagai berikut: "Pengaruh Hasil Program Parenting dan Pola Asuh Orang Tua terhadap Peningkatan Motivasi Belajar Anak Usia Dini."

\section{B. Kajian Teori}

\section{Pengertian Parenting}

Menurut Jerome Kagan (dalam Okvina, 2009) seorang psikolog perkembangan mendefinisikan pengasuhan atau parenting sebagai serangkaian keputusan tentang sosialisasi pada anak, yang mencakup apa yang harus dilakukan oleh orang tua atau pengasuh agar anak mampu bertanggung jawab dan memberikan kontribusi sebagai anggota masyarakat termasuk juga apa yang harus dilakukan orang tua atau pengasuh ketika anak menangis, marah, berbohong, dan melakukan kewajibannya dengan baik. Selanjutnya pendapat lain menyebutkan bahwa pengasuhan merupakan sebuah proses interaksi yang berlangsung terus-menerus dan mempengaruhi bukan hanya bagi anak juga bagi orang tua, menurut ( Berns 1997 dalam Okvina, 2009). 
Dari pemaparan di atas peneliti menyimpulkan bahwa parenting memiliki arti yaitu pengasuhan yang diberikan oleh orang tua terhadap anak. Pengasuhan disini berupa perhatian, perlindungan dan kasih sayang. Pengasuhan merupakan sebuah proses interaksi yang terus menerus dilakukan orang tua terhadap anak untuk mendorong pertumbuhan dan perkembangan anak baik secar fisik maupun secara sosial, dan tidak bisa terlepas dari pengaruh sosial dan budaya tempat anak dibesarkan.

\section{Pengertian Program Parenting}

Istilah program sering disamakan dengan "kurikulum" yang digunakan sebagai referensi dalam sekolah formal. Namun dalam pendidikan nonformal program diartikan lain, didukung oleh Sujana (2008, hlm. 1) program merupakan kegiatan yang dilakukan oleh perorangan, kelompok, atau organisasi (lembaga) dan memuat komponen-komponen tertentu. Sedangkan menurut Mappa (1993, hlm. 1) dalam Hatimah (1998, hlm. 1) program merupakan rangkaian kegiatan yang satu sama lain saling berkaitan dalam mengatasi atau menyelesaikan suatu masalah atau mencapai tujuan yang telah ditetapkan.

Dengan begitu dapat ditegaskan bahwa dilihat dari beberapa pengertian, program pada hakekatnya merupakan akumulasi beberapa kegiatan. Program dapat dilaksanakan oleh individu, kelompok, atau suatu organisasi/lembaga. Program terdiri dari unsur-unsur atau komponen. Program dilaksanakan karena adanya berbagai permasalahan, sehingga tujuan akhirnya adalah memecahkan atau mengatasi permasalahan tersebut.

Pengertian Program Parenting yang dikemukakan dalam Juknis Orientasi Teknis Peningkatan Program Parenting tahun 2011, yaitu: Program Parenting adalah program dukungan yang ditunjukan kepada para orang tua atau anggota keluarga yang lain agar semakin memiliki kemampuan dalam melaksanakan fungsi sosial dan pendidikan dalam hal mengasuh, merawat, melindungi, dan mendidik anaknya dirumah sehingga anak dapat tumbuh dan berkembang secara optimal, sesuai dengan usia dan tahap perkembangannya.

Program parenting bertujuan agar anggota keluarga, khususnya orang tua, pengasuh dan orang-orang dewasa di sekitar anak mampu memiliki pengetahuan dan keterampilan dalam mengasuh dan mendidik anak, sehingga dapat mewujudkan generasi penerus bangsa yang berkualitas dan berkarakter. Melalui program parenting orang tua dapat berbagi masalah yang dihadapi didalam keluarga yang berhubungan dengan pengasuhan anak. Selain itu program 
parenting dapat menjadi orang tua yang berkualitas, tidak hanya mendapatkan pengetahuan mengenai pengasuhan saja tetapi dibekali keterampilan-keterampilan khusus agar orang tua mampu menyesuaikan perkembangan anak.

\section{Pengertian Motivasi Belajar}

Motivasi dan belajar merupakan dua hal yang saling mempengaruhi. Belajar adalah perubahan tingkah laku secara relatif permanen dan secara potensial terjadi sebagai hasi dari praktik atau penguatan yang dilandasi tujuan untuk mencapai tujuan tertentu, menurut (Uno, 2008, hlm. 23). Selanjutnya menurut Sudarwan (2004, hlm. 15), "motivasi diartikan sebagai setiap kekuatan yang muncul dari dalam diri individu untuk mencapai tujuan atau keuntungan tertentu di lingkungan dunia kerja atau di pelataran kehidupan pada umumnya".

Sedangkan menurut Sardiman (2011, hlm. 75), "motivasi dapat juga dikatakan serangkaian usaha untuk menyediakan kondisi-kondisi tertentu, sehingga seseorang mau dan ingin melakukan sesuatu, dan bila ia tidak suka, maka akan berusaha untuk meniadakan perasaan tidak suka itu". Jadi motivasi itu dapat dirangsang oleh faktor dari luar tetapi motivasi itu adalah tumbuh didalam diri seseorang. Dalam kegiatan belajar, motivasi dapat diartikan sebagai keseluruhan daya penggerak di dalam diri individu yang menimbulkan kegiatan belajar, yang menjamin kelangsungan dari kegiatan belajar yang memberikan arah pada kegiatan belajar, sehingga tujuan yang dikehendaki oleh subjek belajar itu dapat tercapai. Ada tiga fungsi motivasi menurut Sardiman (2011, hlm. 85), yaitu:

a. Mendorong manusia untuk berbuat, jadi sebagai penggerak atau motor yang melepaskan energi. Motivasi dalam hal ini merupakan motor penggerak dari setiap kegiatan yang akan dikerjakan.

b. Menentukan arah perbuatan, yakni ke arah tujuan yang hendak dicapai. Dengan demikian motivasi dapat memberikan arah dan kegiatan yang harus dikerjakan, sesuai dengan rumusan tujuannya.

c. Menyeleksi perbuatan, yakni menentukan perbuatan-perbuatan apa yang harus dikerjakan yang serasi guna mencapai tujuan, dengan menyisihkan perbuatanperbuatan yang tidak bermanfaat bagi tujuan tersebut. Seorang siswa yang akan menghadapi ujian dengan harapan dapat lulus, tentu akan melakukan kegiatan belajar 
dan tidak akan menghabiskan waktunya untuk bermain kartu atau membaca komik, sebar tidak serasi dengan tujuan.

Sejalan dengan hal tersebut maka peneliti dapat menyimpulkan bahwa setiap fungsi motivasi bermanfaat untuk merubah perilaku setiap individu untuk memperoleh hasil atau mencapai tujuan tertentu. Selain itu fungsi motivasi juga merupakan pendorong manusia untuk berbuat, menentukan arah perbuatan, untuk mencapai tujuan dan menyeleksi perbuatan mana yang akan dikerjakan. Selain itu motivasi dapat berfungsi sebagai daya pendorong usaha dalam pencapaian prestasi, individu yang ingin berusaha artinya ia memiliki motivasi. Dengan adanya motivasi yang baik dalam belajar, maka akan menunjukan hasil yang baik.

\section{Pola Asuh}

Tujun pengasuhan adalah memberikan pengetahuan dan keterampilan pada anak agar mampu bermasyarakat. Orang tua menanamkan nilai-nilai kepada anak-anaknya untuk membantu mereka membangun kompetensi dan kedamaian, agar mereka mampu menanamkan kejujuran, tanggung jawab, menghormati diri sendiri, memiliki perasaan kasih sayang, dan kerja keras. Dengan latihan dan kedewasaan, karakter-karakter tersebut menjadi bagian utuh kehidupan anak-anak.

Menurut pakar pengembangan anak (Diana Baumrind, dalam Edward 2006, hlm. 76-82), mengelompokan pola asuh kedalam tiga tipe yaitu pola asuh otoritatif/bisa diandalkan, pola asuh otoriter, dan pola asuh permisif. Berikut adalah analisis dari macam-macam pola asuh tersebut :

a. Pola Asuh Otoritatif/ bisa diandalkan

Orang tua yang bisa diandalkan menyeimbangkan kasih sayang dan dukungan emosional dengan struktur dan bimbingan dalam membesarkan anak-anak mereka. Intinya, orang tua yang bisa diandalkan memberikan banyak kasih sayang dan respons yang baik juga menginginkan banyak tanggung jawab. Orang tua yang menggunakan pendekatan ini selalu memberikan contoh yang baik tentang keseimbagan antara kasih sayang dan sikap asertif yang dibutuhkan seseorang untuk menciptakan kehidupan sosial yang sehat.

Sifat anak yang dibesarkan dengan tipe pola asuh ini menunjukan bahwa anak-anak dari orang tua yang bisa diandalkan cenderung memiliki keanggaan diri yang sehat, hubungan positif dengan sebanyanya, percaya diri, mandiri, dan sukses di sekolah. Anak-anak ini juga terlihat 
meiliki masalah emosional yang lebih rendah dibandingkan dengan anak-anak yang dibesarkan dengan tipe pola asuh lain.

\section{b. Pola Asuh Otoriter}

Orang tua otoriter menekankan batasan dan larangan di atas respon positif. Orang tua sangat menghargai anak-anak yang patuh terhadap apa yang diperintahkan kepada mereka dan tidak melawan. Orang tua otoriter menuntut keteraturan, sikap yang sesuai dengan tuntutan masyarakat dan menekankan kepatuhan pada otoritas. Mereka menggunakan hukuman sebagai penegak kedisiplinan dan dengan mudah mengumbar kemarahan serta ketidaksenangan kepada anak-anak mereka. Tentu saja orang tua otoriter tidak selalu bersikap dingin dan tidak responsif, tetapi mereka lebih banyak menutut dan bersikap penuh amarah serta kurang bersikap positif dan mencintai anak-anak mereka.

Sifat anak yang tumbuh dari orang tua otoriter bisa menjadi pemalu, penuh ketakutan, menarik diri, dan beresiko terkena depresi. Mereka bisa jadi sulit membuat keputusan untuk diri mereka sendiri, karena mereka sudah biasa diperintah apa yang harus mereka kerjakan. Orang tua otoriter tidak menoleransi perbedaan pendapat, jadi anak-anak mereka cenderung sulit mandiri.

\section{c. Pola Asuh Permisif}

Orang tua permisif tidak memberikan stuktur dan batasan-batasan yang tepat bagi anakanak mereka, digambarkan dalam dua jenis yaitu orang tua permisif-lunak dan orang tua yang lepas-tangan. Orang tua permisif-lunak bisa hangat, bersifat ngemong, dan responsif, tetapi mereka memberikan sedikit sekali stuktur bimbingan. Karena orang tua dengan tipe ini cenderung mempercayai bahwa ekspresi bebas dari keinginan hati dan harapan sangatlah penting bagi perkembangan psikologis, mereka memberikan sedikit sekali tuntutan kepada anak-anak mereka untuk menjadi matang dan bersikap mandiri.Anak-anak yang dibesarkan oleh tipe orang tua ini biasanya menjadi anak-anak yang manja. Mereka cenderung tidak cocok dengan orang dewasa lainnya. Mereka sangat menuntut, kurang percaya diri, dan kurang bisa mengandalkan diri. Mereka tidak menetapkan tujuan atau menikmati kegiatan yang menanggung tanggung jawab. Mereka bisa jadi senang dan bersikap baik selama segala sesuatu berjalan sesuai dengan keinginan mereka, tetapi mudah frustasi jika keinginan mereka tidak terpenuhi. 
Dari semua pendekatan pola asuh, tipe lepas tangan yang paling banyak menimbulkan dampak negatif bagi anak-anak. Anak-anak ini sangat beresiko memiliki masalah emosi dan perilaku, kesulitan akademis, rendahnya kepercayaan diri, dan kecanduan alkohol atau penyalahgunaan lainnya.

Sebagaimana orang tua otoriter, orang tua permisif tidak selalu melakukan tindakan yang sama. Orang tua permisif lunak terkadang memberikan semacam struktur dan bimbingan, dan orang tua yang permisif lepas tangan kadang-kadang bisa memberikan dukungan dam bimbingan. Namun, masalahnya adalah anak tidak mendapatkan dukungan dan bimbingan yang cukup dari orang tua yang lepas tangan atau larangan yang tegas dari orang tua bertipe permisiflunak. Selanjutnya menurut Baumrind (Weiten \& Lioyd, 1994, hlm. 359-360; Sigelman \& Shaffer, 1995, hlm. 396) dalam Yusuf (2011, hlm. 51-52), mengemukakan hasil penelitiannya melalui observasi dan wawancara terhadap siswa taman kanak-kanak. Penelitian ini dilakukannya, baik di rumah maupun di sekolahnya.

\section{Hasil dan Pembahasan}

Pada penelitian yang mengungkapkan tentang pengaruh hasil program parenting dan pola asuh orang tua terhadap peningkatan motivasi belajar anak usia dini survey terhadap orang tua pada TK ABA 3 Padangsidimpuan ini dapat diukur dengan menyebarkan angket kepada responden yang sudah ditentukan. Kemudian hasil angket tersebut diolah datanya dengan perhitungan yang sudah ada. Dari hasil perhitungan yang didapat tentunya memerluka pembahasan yang lebih mendalam dan menyeluruh. Berikut ini adalah pembahasan hasil penelitian :

\section{Pengaruh hasil program parenting terhadap pola asuh orang tua}

Berdasarkan hasil analisa data yang diperoleh dari penyebaran kuesioner kepada 50 responden/peserta program parenting di TK ABA 3 Padangsidimpuan, maka dapat disimpulkan bahwa pengaruh program parenting terhadap pola asuh orang tua yaitu sebesar 78,5\%, artinya hasil program parenting memiliki pengaruh yang cukup tinggi terhadap pola asuh orang tua.

Hal ini sejalan dengan yang diungkapkan oleh Juknis Orientasi Teknis Peningkatan Program Parenting tahun 2011, dikemukakan tujuan khusus diselenggarakannya program parenting, yaitu sebagai berikut: 
a. Agar orang tua semakin memiliki kemampuan dan keterampilan dalam melaksanakan fungsi sosial dan pendidikan dalam hal mengasuh, merawat, melindungi, dan mendidik anaknya di rumah sehingga anak dapat tumbuh dan berkembang secara optimal, sesuai dengan usia dan tahap perkembangannya.

b. Meningkatkan kesadaran orang tua sebagai pendidik yang pertama dan utama. Sehingga tidak ada lagi persepsi dari orang tua yang beranggapan bahwa pendidikan anak sepenuhnya adalah tanggung jawab pihak lembaga pendidikan yang bersangkutan.

c. Meningkatkan dukungan keluarga, khususnya dukungan para orang tua dalam proses pendidikan anak dalam suatu lembaga pendidikan.

d. Memberdayakan orang tua dalam pengasuhan anak yang sesuai dengan keunikan dan karakteristik anak.

Dengan begitu analisa di lapangan menunjukan bahwa pengaruh hasil program parenting terhadap pola asuh orang tua berupa pembiasaan pada anak, mengajarkan anak bertutur kata dengan baik, mengetahui cara-cara mendidik anak dengan baik, menambah pengetahuan orang tua mengenai penerapan pengasuhan terhadap anak, memberikan pemahan mengenai karakter anak, mengetahui kebutuhan belajar anak, memberikan pengetahuan cara menghadapi sifat anak, terbiasa melihat perkembangan belajar anak, dan mengawasi anak bermain. Skor rata-rata jawaban responden diperoleh dengan nilai sebesar 157 dengan perolahan persentase sebesar 78,5\%. Lebih dalam lagi ternyata program parenting ini juga sangat berpengaruh terhadap kesiapan orang tua dalam hal mendidik anak, tidak mudah khawatir terhadap perilaku anak yang sewaktu-waktu berubah. Menjadikan orang tua

\section{Pengaruh pola asuh yang diterapkan orang tua terhadap peningkatan motivasi belajar anak usia dini}

Berdasarkan hasil perhitungan dari data yang diperoleh melalui 50 orang responden/peserta program parenting di TK ABA 3 Padangsidimpuan dapat dilihat hasil perhitungan pengaruh pola asuh yang diterapkan orang tua terhadap peningkatan motivasi belajar anak usia dini diperoleh melalui hasil perhitungan tipe pola asuh yang diterapkan oleh peserta program parenting di TK ABA 3 Padangsidimpuan yaitu pola asuh dengan kategori rendah atau identik dengan tipe pola asuh demokratis sebesar 54\% dengan jumlah 27 orang, 
sedangkan kategori pola asuh sedang atau tipe pola asuh permisif sebesar $38 \%$ dengan jumlah 19 orang dan pola asuh dengan kategori tinggi atau tipe pola asuh otoriter sebesar $8 \%$ sebanyak 4 orang.

Hal ini sejalan dengan yang diungkapkan oleh Syamsu Yusuf (2011) dijelaskan bahwa pegaruh parenting styles terhadap perilaku anak yaitu authoritarian/otoriter berdampak pada perilaku anak menjadi mudah tersinggung, penakut, pemurung/tidak bahagia, mudah terpengaruh, mudah stres, tidak mempunyai arah masa depan yang jelas, tidak bersahabat. Permissive berdampak pada perilaku anak menjadi besikap implulsif dan agresif, suka memberontak, kurang memiliki rasa percaya diri dan pengendalian diri, suka mendominasi, tidak jelas arah hidupnya, prestasinya rendah. Selanjutnya authoritative/demokratis berdampak pada perilaku anak menjadi bersikap bersahabat, memiliki rasa percaya diri, mampu mengendalikan diri, sopan, mau bekerja keras, memiliki rasa ingin tahu yang tinggi, mempunyai tujuan/arah hidup yang jelas, berorientasi terhadap prestasi.

Dengan begitu motivasi belajar anak dapat dilihat hasil melalui persamaan pada tabel regresi bahwa setiap perubahan satu satuan pola asuh orang tua, maka akan terjadi peningkatan pada motivasi belajar anak usia dini sebesar 0,416. Selanjutnya nilai probabilitas t-hitung variabel pola asuh orang tua sebesar 0,001 menunjukan hipotesis alternatif $\left(\mathrm{H}_{\mathrm{a} 1}\right)$ yang diajukan diterima, yang berarti pola asuh orang tua secara parsial berpengaruh terhadap motivasi belajar anak usia dini.

\section{Pengaruh hasil program parenting dan pola asuh yang diterapkan orang tua terhadap peningkatan motivasi belajar anak usia dini}

Ketika hasil program parenting di TK ABA 3 Padangsidimpuan sesuai dengan tujuan yang telah ditetapkan, kemudian sesuai dengan kebutuhan peserta program parenting maka hasil dari program parenting akan berdampak baik terhadap pola asuh orang tua, dan secara otomatis ketika pengetahuan mengenai pola asuh yang didapat pada program parenting apabila diterapkan dengan baik maka akan berdampak baik pula terhadap peningkatan motivasi belajar anak. Dengan begitu hasil data kuesioner pada 50 orang responden/peserta program parenting di TK ABA 3 Padangsidimpuan mengenai pengaruh hasil program parenting dan pola asuh yang diterapkan orang tua terhadap peningkatan motivasi belajar anak usia dini diperoleh dengan skor sebesar 3475 atau sebesar 75,54\%. Hasil tersebut menunjukan bahwa motivasi belajar anak usia 
dini yang orang tuanya menjadi peserta program parenting di TK ABA 3 Padangsidimpuan dinyatakan dengan kriterian tinggi.

Berdasarkan hasil pengolahan data pada persamaan regresi bahwa setiap kenaikan satuan pada hasil program parenting dan pola asuh orang tua diikuti oleh kenaikan motivasi belajar anak usia dini sebesar -1.470 satuan. Artinya setiap perubahan satu satuan hasil program parenting, maka akan terjadi peningkatan pada motivasi belajar anak usia dini sebesar 0,569 dan setiap perubahan satu satuan pola asuh orang tua, maka akan terjadi peningkatan pada motivasi belajar anak usia dini sebesar 0,416.

Hasil pengolahan data pada uji anova untuk mengetahui uji kelayakan model analisis, dimana variabel independent mempengaruhi variabel depndent diperoleh dengan hasil nilai $\mathrm{F}$ (F-hitung) sebesar 42,934 sedangkan F-tabel 2,570. Maka diketahui bahwa F-hitung 42,934 > Ftabel 2,570 atau dengan kata lain hipotesis nol (Ho) ditolak, kesimpulannya yaitu variabel hasil program parenting $\left(\mathrm{X}_{1}\right)$ dan pola asuh orang tua $\left(\mathrm{X}_{2}\right)$ secara bersama-sama berpengaruh terhadap motivasi belajar anak usia dini (Y).

Hal tersebut sejalan dengan yang diungkapkan oleh Sardiman (2011,hlm.89-91) bahwa terdapat motivasi intrinsik dan ekstrinsik yang artinya:

a. Motivasi Intrinsik, motif-motif yang menjadi aktif atau berfungsinya tidak perlu dirangsang dari luar, karena dalam diri setiap individu sudah ada dorongan untuk melakukan sesuatu.

b. Motivasi ekstrinsik, motif-motif yang aktif dan berfungsinya karena adanya perangsang dari luar.

Sejalan dengan hal tersebut, maka dapat menyimpulkan dari berbagai macam motivasi dapat berpengaruh terhadap keinginan setiap individu untuk mencapai prestasi. Perlu diketahui bahwa motivasi bersumber dari dorongan yang menggerakkan itu bersumber pada suatu kebutuhan, kebutuhan yang berisikan keharusan menjadi orang yang terdidik dan berpengetahuan. Selain itu perlu ditegaskan bahwa dalam kegiatan belajar tidak selamanya menarik, tetapi juga akan merasa bosan atau jenuh sehingga harus didukung oleh dorongan atau dukungan dari lingkungan. 


\section{Penutup}

Secara umum penelitian ini dapat disimpulkan dengan terbuktinya hipotesis yang menyatakan bahwa terdapat pengaruh yang signifikan antara hasil program parenting dan pola asuh orang tua terhadap peningkatan motivasi belajar anak usia dini di TK ABA 3 Padangsidimpuan. Hal tersebut dapat dilihat pada uraian dibawah ini:

a. Hasil program parenting memiliki pengaruh yang cukup tinggi terhadap pola asuh orang tua. Orang tua yang mengikuti program parenting di TK ABA 3 Padangsidimpuan sebagian besar dapat menerapkan materi-materi yang disampaikan pada saat kegiatan tersebut dilaksanakan ke dalam pengasuhan pada anak setiap harinya. Wawasan yang didapatkan orang tua semakin meningkat dengan adanya program parenting, selain itu juga hasil dari program parentng memberikan pengaruh yang positif terhadap pola asuh orang tua. Hal tersebut didasari karena hasil program parenting yang dilaksanakan di TK ABA 3 Padangsidimpuan memenuhi aspek yang telah ditetapkan.

b. Pola asuh orang tua secara parsial berpengaruh terhadap peningkatan motivasi belajar anak usia dini. Secara umum pola asuh yang diterapkan orang tua yang mengikuti program parenting di TK ABA 3 Padangsidimpuan yaitu pola asuh dengan kategori rendah sebesar 54\% dengan jumlah 27 orang, sedangkan kategori pola asuh sedang sebesar 38\% dengan jumlah 19 orang dan pola asuh dengan kategori tinggi sebesar $8 \%$ sebanyak 4 orang. Hal tersebut menunjukan bahwa pola asuh yang sangat berpengaruh terhadap peningkatan motivasi belajar anak usia dini yang diterapkan oleh orang tua di TK ABA 3 Padangsidimpuan yaitu dengan kategori rendah atau identik dengan tipe pola asuh demokratis.

c. Hasil program parenting dan pola asuh yang diterapkan oleh orang tua memiliki pengaruh terhadap peningkatan motivasi belajar anak usia dini. Hal tersebut dapat dilihat melaui hasil dari program parenting telah memenuhi aspek yang telah ditetapkan, selain itu orang tua mampu menerapkan pengetahuan yang didapat pada saat program parenting yang telah dilaksanakan di TK ABA 3 Padangsidimpuan. Motivasi belajar anak usia dini berada pada 
tingkat tinggi setelah mendapat perlakuan dari hasil program parenting dan pola asuh orang tua yang secara bersama-sama berpengaruh terhadap motivasi belajar anak usia dini.

\section{A. Saran}

Dari hasil penelitian ini adapun saran yang dapat peneliti berikan bagi pihak-pihak terkait, yaitu sebagai berikut:

\section{a. Bagi Keluarga}

Dari hasil penelitian ini diharapkan untuk keluarga yang menjadi peserta ptrogram parenting terus mengikuti keiatan tersebut, maupun keluarga yang belum menjadi peserta program parenting dan memiliki anak usia dini diharapkan agar ikut serta dalam kegiatan tersebut. Karena program parenting ini banyak memberikan manfaat untuk membantu pengasuhan anak yang terjadi di lingkungan keluarga maupun lingkungan masyarakat. Selain itu juda dapat memberikan banyak wawasan dan pengetahuan bagi orang tua yang memiliki anak dalam hal pengasuhan agar lebih baik dari sebelumnya.

\section{b. Bagi Lembaga Penyelenggara Program Parenting}

Diharapkan untuk pihak lembaga penyelenggara program parenting agar terus mengembangkan kegiatan tersebut sesuai dengan kebutuhan peserta, karena sangat bermanfaat bagi orang tua. Kemudian untuk pemilihan narasumber, agar tidak terjadi rasa bosan bagi peserta maka dalam penyelenggaraan setidaknya sebulan sekali mengundang narasumber dari pihak luar yang bersangkutan. Hal tersebut agar kegiatan parenting tetap diminati oleh orang tua.

\section{c. Bagi Peneliti Selanjutnya}

Bagi peneliti selanjutnya yang berminat melakukan penelitian dengan kajian yang sama diharapkan dapat lebih mengembangkan penelitian ini. Penelitian terhadap hasil dari program parenting dan pola asuh yang diterapkan orang tua terhadap peningkatan motivasi belajar anak usia dini. Sehingga hasil dapri program parenting dan perbedaan pengasuhan akan terlihat dalam meningkatkan motivasi belajar anak usia dini.

\section{Daftar Pustaka}

AM, Sardiman. (2011). Interaksi dan Motivasi Belajar Mengajar. Jakarta: PT RajaGrafindo Persada. 
Danim, Sudarwan. (2004). Motivasi Kepemimpinan \& Efektivitas Kelompok. Jakarta : Rineka Cipta.

Edwards, C. Drew. (2006). Ketika Anak Sulit Diatur: Panduan Bagi Para Orangtua untuk mengubah Masalah Perilaku Anak. Bandung: Kaifa.

Hatimah, I. (1998). Supervisi Monitoring Pendidikan Luar Sekolah. Bandung: Lab PLS.

Kementrian Pendidikan Nasional. (2011). Petunjuk Teknis Orientasi Teknis Peningkatan Pemahaman Program Penguatan PAUD Berbasis Keluarga (Parenting). Jakarta: Kemendiknas.

Sudjana, D. (2010). Manajemen Program Pendidikan. untuk Pendidikan Nonformal dan Pengembangan Sumber Daya manusia. Bandung: Falah Production.

Uno, Hamzah B. (2008). Teori Motivasi dan Pengukurannya. Jakarta: Bumi Aksara.

Yusuf, Syamsu. (2011). Psikologi Perkembangan Anak \& Remaja. Bandung: Rosada.

\section{Sumber Internet:}

Okvina. (2009). Konsep Pengasuhan (Parenting). [Online]. Tetsedia: https://okvina.wordpress.com/2009/02/18/konsep-pengasuhan-parenting. (9 Januari 2015).

Undang-Undang Republik Indonesia No 20 tahun 2003. Tendang Sistem Pendidikan Nasional. [Online]. Tersedia: http://usu.ac.id/public/content/files/sisdiknas.pdf. ( 2 Agustus 2014 ) 
